\title{
BIRC6 (APOLLON) is down-regulated in acute myeloid leukemia and its knockdown attenuates neutrophil differentiation
}

\author{
Anna M Schläfli ${ }^{1}$, Bruce E Torbett ${ }^{2}$, Martin F Fey ${ }^{1,3}$ and Mario P Tschan ${ }^{1,3^{*}}$
}

\begin{abstract}
Background: Inhibitors of apoptosis (IAPs) were intensively investigated in the context of cancer where they promote tumor growth and chemoresistence. Overexpression of the IAP BIRC6 is associated with unfavorable clinical features and negatively impacts relapse-free survival in childhood acute myeloid leukemia (AML). Currently, BIRC6 levels in adult primary AML have not been compared to the expression in normal myeloid cells. Thus, we compared for the first time BIRC6 levels in adult primary AML patient samples to normal myeloid cells and studied its regulation and function during neutrophil differentiation.
\end{abstract}

Findings: We found significantly lower BIRC6 levels in particular AML subtypes as compared to granulocytes from healthy donors. The lowest BIRC6 expression was found in $\mathrm{CD} 34^{+}$progenitor cells. Moreover, BIRC6 expression significantly increased during neutrophil differentiation of AML cell lines and knocking down BIRC6 in NB4 acute promyelocytic leukemia (APL) cells significantly impaired neutrophil differentiation, but not cell viability.

Conclusion: Together, we found an association of low BIRC6 levels with an immature myeloid phenotype and describe a function for BIRC6 in neutrophil differentiation of APL cells.

Keywords: BIRC6, Acute myeloid leukemia, Acute promyelocytic leukemia, ATRA, Neutrophil differentiation

\section{Introduction}

BIRC6 (a.k.a. APOLLON, BRUCE) is an exceptionally large protein of $528 \mathrm{kDa}$ belonging to the family of inhibitor of apoptosis (IAP). BIRC6 contains one bacalovirus IAP repeat (BIR) domain that shows homology to the IAP Survivin. Furthermore, BIRC6 is the only IAP with an ubiquitin-conjugating domain further pointing to a particular function of this protein in the IAP family [1]. Several groups reported that BIRC6 executes its function via inhibition of Smac and Caspase-9 [2,3]. Moreover, a study in breast cancer cells revealed that BIRC6 inhibits cell death by $p 53$ destabilization and inactivation of caspase-3 [4]. The role of p53-dependent BIRC6 effector functions was

\footnotetext{
* Correspondence: mtschan@dkf.unibe.ch

'Experimental Oncology/Hematology, Department of Clinical Research,

University of Bern, Murtenstrasse 35, CH-3010, Bern, Switzerland

${ }^{3}$ Department of Medical Oncology, Inselspital, Bern University Hospital, Bern, Switzerland

Full list of author information is available at the end of the article
}

confirmed by investigations of Ren et al. in mice and human lung cancer cells [5].

Due to their anti-apoptotic function it was hypothesized that overexpression of IAPs might contribute to tumorigenesis. Survivin, for example, one of the best studied IAPs is up regulated in most tumors and has been associated with their chemoresistence [6, 7]. Recently, Houdt et al. [8] observed BIRC6 overexpression in colon cancer stem cells when compared to more differentiated tumor cells. BIRC6 expression protected colon cancer stem cells from the cytotoxic effects of oxaliplatin and cisplatin. Furthermore, knocking-down BIRC6 led to growth inhibition in several cancer cell lines and xenografted mice and rendered the tumor cells more sensitive to 5-fluoruracil treatment in vivo and in vitro [9]. The significance of IAPs in the pathology of hematological malignancies however remains poorly understood and controversial data regarding an effect on prognosis were published. Carter et al. [10] did not find any prognostic significance for Survivin or XIAP expression in adult AML samples, whereas BIRC6 
overexpression is associated with unfavorable clinical features and negatively impacts on the 3-year relapsefree survival in childhood acute myeloid leukemia (AML) [11]. Similar results were obtained by Ismail et al. in childhood AML and acute lymphoblastic leukemia (ALL) [12]. Abe et al. [13] found lower expression of BIRC6 in bone marrow-derived cells of healthy donors compared to de novo AML samples.

To our knowledge, BIRC6 levels in primary AML have never been compared to the respective expression in normal myeloid cells. Thus, we aimed at comparing BIRC6 levels in a large cohort $(\mathrm{n}=98)$ of adult AML patient samples and mature neutrophils from healthy donors. Since a hallmark of AML is a differentiation block of hematopoietic precursors at different developmental stages and since this block can be overcome by treating acute promylocytic leukemia (APL) patients with all-trans retinoic acid (ATRA) and low dose chemotherapy, we also analyzed the role of BIRC6 during neutrophil differentiation of AML cells.

\section{Materials and methods Primary patient samples}

A cohort of 98 samples from patients with a diagnosis of primary AML (FAB M0-M4) were enrolled on HOVON/ SAKK (Dutch-Belgian Hematology-Oncology/ Swiss Group for Clinical Cancer Research Cooperative group) protocols $-04,-04 \mathrm{~A},-29$, and -42 (available at www. hovon.nl) between 1987 and 2006 [14-18]). All patients provided written informed consent in accordance with the Declaration of Helsinki. Patient data are summarized in the Table 1 . In vitro differentiation of $\mathrm{CD} 4^{+}$progenitor cells was done as previously described [19].

\section{Cell lines and culture conditions}

The acute myeloid leukemia (AML) cell lines HL60, FAB M2, the ATRA-resistant subline HL60-R, NB4, FAB M3 (acute promyelocytic leukemia; APL), the ATRAresistant subline NB4-R2 and HT93 were kept in RPIMI-1640 culture media (Sigma-Aldrich, Buchs, Schweiz) containing $10 \%$ foetal bovine serum (FBS). In order to differentiate the AML cell lines towards granulocytes $1 \mu \mathrm{M}$ all-trans retinoic acid (ATRA) was added to the cells that were seeded at a density of $0.2 \times 10^{6}$ cells $/ \mathrm{ml}$. Successful neutrophil differentiation was assessed by CD11b surface and by increased granulocyte colony-stimulating factor receptor (G-CSFR; CSF3R) mRNA expression.

\section{Quantitative real-time RT-PCR (qPCR) and TaqMan Low Density Array (LDA)}

For RNA extraction the miRCURY RNA Isolation Kit from Exiqon was used. RT-PCR has been described elsewhere [19]. Quantitative measurement of BIRC6 and G-CSFR mRNA was performed using the $\operatorname{TaqMan}^{\circledR}$ Gene Expression assays Hs00212288_m1 and Hs00167918_m1, respectively (Applied Biosystems, Rotkreuz, Switzerland). LDA measurements as well as data analysis were done as described [20]. HMBS primers and probes have been described previously [21]. Measurements were carried out on an ABI PRISM 7500 Sequence Detection System (Applied Biosystems, Rotkreuz, Switzerland).

\section{Generation of BIRC6 knock-down cell lines}

NB4 cells were transduced with a lentiviral vector (pLKO.1) expressing a small hairpin (sh)RNA targeting the BIRC6 mRNA (NM_016252.x-2281s1c1, SigmaAldrich, Buchs, Schweiz). Lentivirus production has been described previously [19]. As a non-targeting control we used the SHCOO2 lentiviral vector. Two days after transduction, NB4 cells were selected with $1.5 \mathrm{ug} / \mathrm{ml}$ puromycin (Sigma-Aldrich, Buchs, Schweiz) for one week.

\section{Cell viability assay}

For Trypan blue exclusion assay cells were washed with PBS before diluting 1:10 in 0.4 \% Trypan blue solution (Sigma-Aldrich, Buchs, Switzerland). For AnnexinV staining $1 \times 10^{5}$ cells were washed in $500 \mu \mathrm{l}$ binding buffer (PBS with $0.33 \mathrm{~g} / \mathrm{L} \mathrm{Ca}^{2+}$ ) and resuspended in a final volume of $100 \mu \mathrm{l} .5 \mu \mathrm{l}$ AnnexinV-PE were added (Immunotools, Germany) and the samples were incubated for 15 minutes at room temperature, before FACS analysis.

Table 1 AML patient characteristics from the HOVON/SAKK cohort

\begin{tabular}{|c|c|c|c|c|c|c|c|c|c|c|c|c|c|c|}
\hline \multirow[b]{2}{*}{ Cohort } & \multirow[b]{2}{*}{ Variables } & \multicolumn{3}{|c|}{ Patient characteristics } & \multicolumn{5}{|c|}{ FAB classification } & \multicolumn{5}{|c|}{ Cytogenetics } \\
\hline & & Age $(y)$ & Sex (female/male) & Total & MO & M1 & M2 & M3 & M4 & $\mathrm{t}(8 ; 21)$ & $\operatorname{inv}(16)$ & $t(15 ; 17)$ & CK & $\overline{N K}$ \\
\hline \multirow[t]{3}{*}{ HOVON/ SAKK } & Range & $17-74$ & - & - & & & & & & & & & & \\
\hline & Mean $/$ median $/ \%$ & $\begin{array}{c}\text { 43.09/43.00 } \\
\text { (mean/median) }\end{array}$ & $59.18 / 40.82$ & 100 & 4.08 & 16.33 & 32.65 & 19.39 & 27.55 & 20.41 & 17.35 & 20.41 & 23.47 & 18.37 \\
\hline & No. of patients & & $58 / 40$ & 98 & 4 & 16 & 32 & 19 & 27 & 20 & 17 & 20 & 23 & 18 \\
\hline
\end{tabular}

$F A B$, French-American-British; $C K$, complex karyotype; NK, normal karyotype. 


\section{Statistical analysis}

Differences between two groups were assessed using the non-parametric Mann-Whitney-U test. P-values $<0.05$ were considered to be statistically significant.

\section{Results}

\section{Repression of BIRC6 mRNA in AML patients with} particular chromosomal aberrations

To study the BIRC6 expression patterns in normal versus leukemic myeloid cells, we measured BIRC6 levels in a large cohort of 98 primary AML patients (FAB M0M4), in 24 granulocyte preparations from healthy donors and in $3 \mathrm{CD} 4^{+}$progenitor cell samples. We were able to detect BIRC6 in 95/98 AML patient, in 14/24 granulocytes and in $3 / 3 \mathrm{CD} 4^{+}$progenitor cell samples. Surprisingly, we found significantly lower BIRC6 levels in AML patients with the translocations $\mathrm{t}(8 ; 21)$ and $\mathrm{t}$ $(15 ; 17)$ as well as in AML patients with a complex karyotype, whereas no significant differences in BIRC6 expression was found in AML patients with inv(16) or normal karyotype as compared to its expression levels in granulocytes from healthy donors (Figure 1). We found the lowest BIRC6 mRNA levels in in $\mathrm{CD}_{34}{ }^{+}$progenitor cells (Figure 1). Together, our data suggest an association of low BIRC6 expression with an immature myeloid phenotype.

\section{Significant BIRC6 inductions during ATRA-induced neutrophil differentiation}

In order to assess a possible role of BIRC6 in neutrophil differentiation of AML cells, we took advantage of several AML cells line models for neutrophil

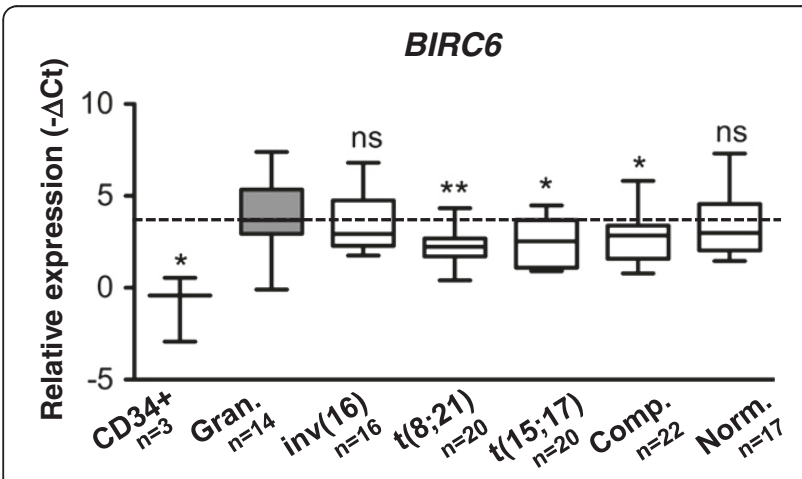

Figure 1 BIRC6 mRNA expression is significantly lower in particular AML subtypes as compared to granulocytes. Relative expression levels of BIRC6 mRNA were determined by $\mathrm{qPCR}$ analysis. Raw $C t$ values were normalized to HMBS and ABL1 $(-\Delta C t)$ and represent $\log _{2}$ expression levels. BIRC6 expression in AML subtypes FAB M0-M4 and the following molecular lesions: (inv(16), $\mathrm{t}(8 ; 21), \mathrm{t}(15 ; 17)$, Comp. $=$ Complex Karyotype, Norm. = Normal Karyotype). Relative BIRC6 expression levels were compared to the relative expression in granulocytes from healthy donors (Gran.) and $\mathrm{CD}^{+}{ }^{+}$progenitor cells. Mann-Whitney $U$ test ${ }^{*} p<0.05$, ${ }^{*} p<0.01$, ns not significant. differentiation. First, we differentiated NB4 APL cells with ATRA towards neutrophils. In accordance with the low BIRC6 expression in undifferentiated AML patients compared to mature neutrophils, BIRC6 mRNA levels were up-regulated 1.8- and 3.6-fold at day 4 and 6 of ATRA treatment, respectively (Figure 2A). In order to exclude a direct effect of ATRA on BIRC6 expression, we also treated ATRA-resistant NB4-R2 APL cells with ATRA. BIRC6 transcripts were only marginally up-regulated in these cells further supporting a particular role of BIRC6 in neutrophil differentiation (Figure 2B). Neutrophil differentiation of NB4 and NB4-R2 cells was assessed by CD11b surface expression (Figure 2C). A similar induction of BIRC6 mRNA expression upon neutrophil differentiation was seen in HT93 APL cells (data not shown). In a further experiment, we determined BIRC6 expression in HL60 and ATRA-resistant HL60-R AML cells during neutrophil differentiation. We observed a significant 1.6- and 2.8fold increase of BIRC6 transcript expression at day 4 and 6, respectively. No significant change in BIRC6 expression was seen in HL60-R cells upon 4 days of ATRA treatment, whereas at day 6 a minor but significant increase was seen (Figure 2D and E). Neutrophil differentiation in HL60 cells was confirmed by CD11b FACS analysis (Figure 2F). ). Consistent with our data showing increased BIRC6 expression upon neutrophil differentiation of NB4 and HL60 AML cells, we observed a 3.3- and 2.8-fold increase in BIRC6 mRNA expression at day 3 and 6 upon in vitro granulocytic differentiation of $\mathrm{CD} 4^{+}$progenitor cells, respectively (data not shown).

Overall, our findings clearly show an association of increased BIRC6 expression with neutrophil development of AML and CD34 $4^{+}$progenitor cells.

\section{Knocking down BIRC6 attenuates neutrophil differentiation but not cell death and proliferation of APL cells}

To test if specific BIRC6 depletion inhibits neutrophil differentiation of APL cells, we generated NB4 BIRC6 knockdown cells. BIRC6 knockdown efficiency was confirmed in control and ATRA-treated shBIRC6 expressing NB4 cells (Figure 3A). Neutrophil development as determined by G-CSFR mRNA as well as CD11b surface expression was on average $50 \%$ reduced compared to the non-targeting control transduced NB4 cells at day 4 of ATRA treatment (Figure 3B-C).

Since BIRC6 is involved in the inhibition of apoptosis, we were asking if the observed lack of neutrophil differentiation in NB4 BIRC6 knockdown cells is due to increased cell death in these cells. For this purpose we assessed cell death by Trypan blue exclusion and Annexin V flow cyotometry at day 4 and 6 of ATRA 


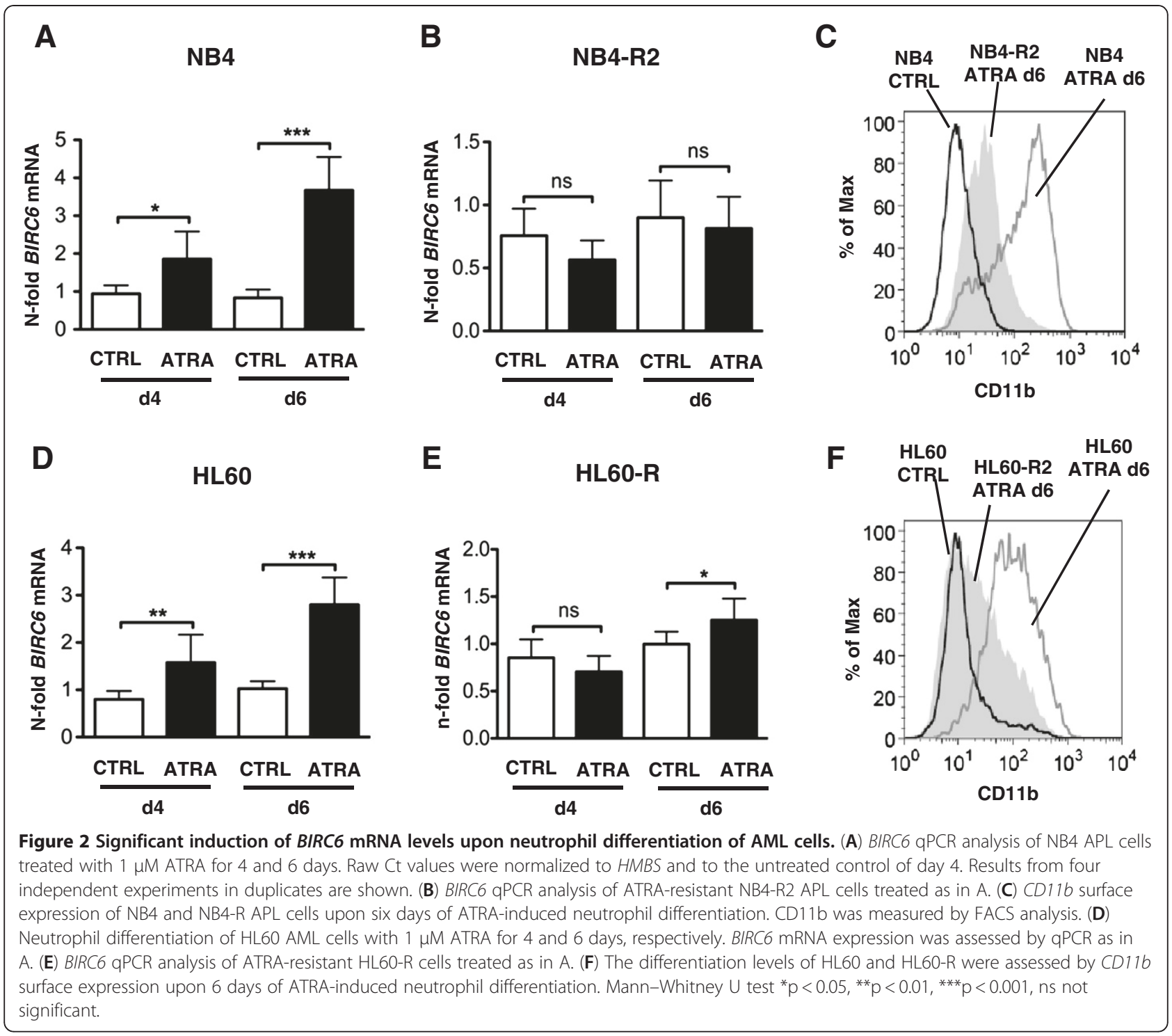

treatment. We did not find any significant differences in cell viability between NB4 control and BIRC6 knockdown cells during ATRA-induced neutrophil differentiation (Figure 3D and E). Furthermore, control transduced as well as BIRC6 knockdown NB4 cells showed no significant differences in total cell counts at day 4 and 6 of ATRA treatment (Figure 3F).

In summary, we showed that inhibiting BIRC6 significantly affects neutrophil differentiation of APL cells, but not cell viability.

\section{Discussion}

In this report we publish for the first time that AML patient samples with the $t(8 ; 21)$, the $t(15 ; 17)$ or a complex karyotype express BIRC6 significantly lower than normal human granulocytes. Subtype-specific BIRC6 expression in AML is supported by earlier findings published by
Ismail et al. [12]. Low expression of the anti-apoptotic IAP BIRC6 in AML may seem controversial given the often high expression of IAPs in cancer. Our findings of high BIRC6 expression in granulocytes versus AML may reflect the cellular differentiation status of these cells rather than a cancer-associated deregulation. This hypothesis is confirmed by our observation that BIRC6 mRNA levels are clearly reduced in $\mathrm{CD} 34^{+}$myeloid precursor cells and increase during granulocyte differentiation. These data are in line with previous findings showing that BIRC6 is down-regulated in bone marrow-derived cells if compared to de novo AML samples [13]. Furthermore, the expression of the BIRC6 related XIAP is induced upon monocyte differentiation and contributes to monocyte cell survival. In the same study, XIAP levels declined during neutrophil differentiation supporting the cell type specific regulation of IAPs in 

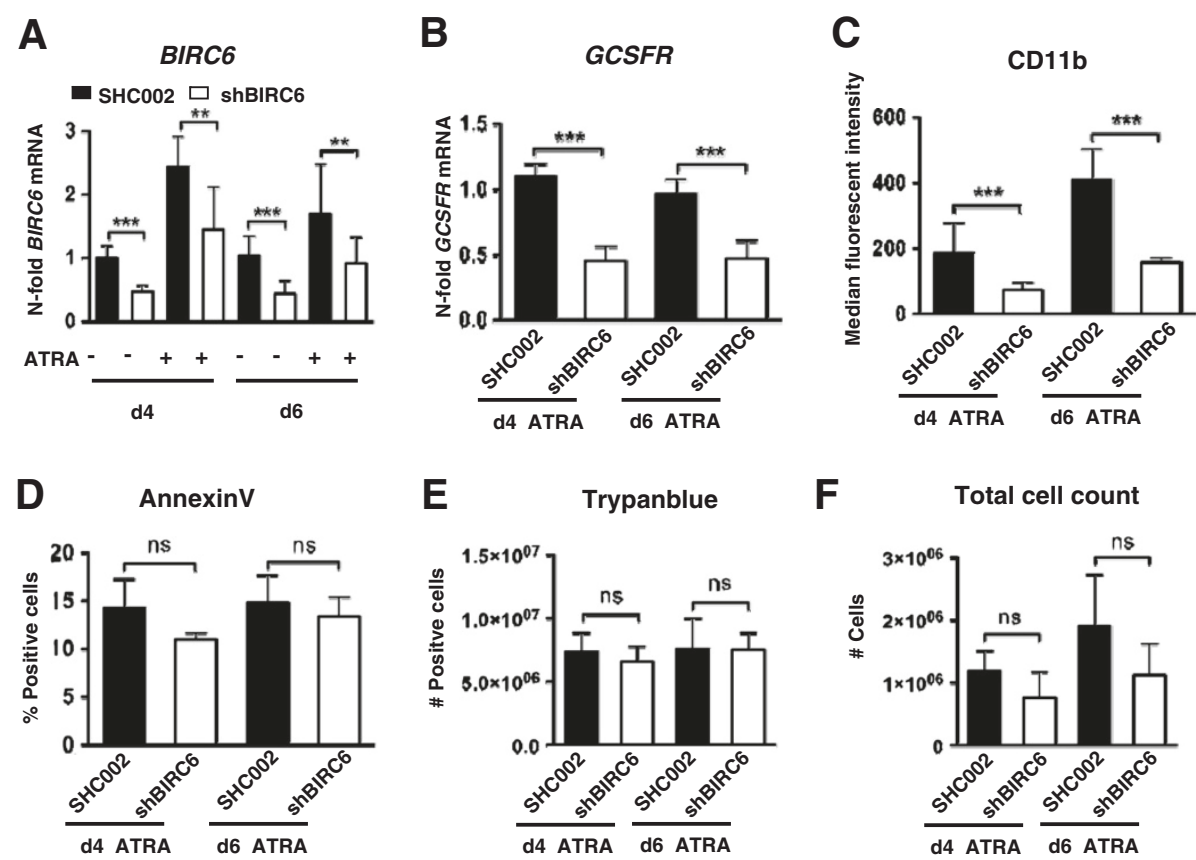

$\mathbf{F}$

Total cell count

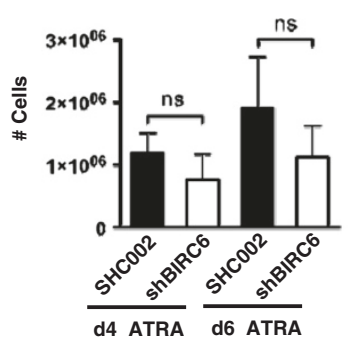

Figure 3 Knocking-down BIRC6 attenuates neutrophil differentiation of APL cells. (A) NB4 BIRC6 knock-down cells (shBIRC6) were generated by lentiviral transduction of shRNAs targeting the BIRC6 mRNA. BIRC6 knockdown efficiency compared to control transduced (SHC002) NB4 cells was determined by qPCR analysis. Values are shown as n-fold regulation compared to control transduced cells. (B,C) NB4 shBIRC6 and SHC002 were treated with $1 \mu \mathrm{M}$ ATRA for 4 and 6 days, respectively. Neutrophil differentiation was determined by G-CSFR mRNA and CD11b surface expression. The raw Ct values of G-CSFR were normalized to HMBS and to the Ct values of the respective control transduced cells under ATRA treatment. CD116 expression is shown as mean fluorescence intensity (MFI). (D,E) Cell death in BIRC6 knock-down cells at day 4 and 6 of ATRA treatment was assessed by AnnexinV staining and Trypanblue exclusion assays. Data are given as percentage or total number of death cells, respectively. (F) Total cell counts were determined using a hemocytometer. There was no difference in total cell number at day 4 or 6 of ATRA treatment between shBIRC6 or control NB4 cells. Mann-Whitney $U$ test ${ }^{* *} p<0.01$, ${ }^{* *} p<0.001$, ns not significant.

myeloid cells [22]. Consistent with the monocyte specific expression of XIAP, a correlation of XIAP levels with monocytic markers in AML was found [23]. In contrast to these finding in adult AML, in childhood de novo acute myeloid leukemia the levels of XIAP correlated with an immature FAB-subtype [24]. This may suggest different XIAP functions in distinct leukemic entities.

In conclusion, we were able to link increased BIRC6 mRNA expression with neutrophil differentiation and inhibiting BIRC6 resulted in attenuated neutrophil differentiation but did not alter cell survival. In summary, we established a new role for BIRC6 in neutrophil differentiation of AML cells.

\section{Abbreviations \\ IAP, Inhibitor of apoptosis; AML, Acute myeloid leukemia; APL, Acute promyelocytic leukemia; ATRA, All-trans retinoic acid; BIR, Bacalovirus IAP repeat; ALL, Acute lymphoblastic leukemia.}

\section{Competing interest}

No competing interest to be declared.

\section{Author's contributions}

AS performed the experimental research, interpreted the data and drafted the article. BET provided primary cells and essential reagents, analyzed patient data and revised the article. MFF investigated the initial concept and experimental design and revised the drafted article. MPT designed the project and gave final approval of the submitted manuscript. All authors read and approved the final manuscript.

\section{Acknowledgments}

We gratefully acknowledge Dr. P.J.M. Valk and Dr. B. Löwenberg and the HOVON (Dutch-Belgian Hematology-Oncology) cooperative group for providing primary AML patient samples. Deborah Shan and Joy Chen are acknowledged for excellent technical support. This work was supported by grants from Cancer Research Switzerland KFS 02486-08-2009 (to MPT), the Bern University Research Foundation (to MPT), the Ursula-Hecht-Foundation for Leukemia Research (to MFF), the Bernese Foundation of Cancer Research (to MFF), the Marlies-Schwegler Foundation (to MFF), the Werner and Hedy Berger-Janser Foundation of Cancer Research (to MFF and MPT), and the Joyce Klein Stock Gift and NIH R01HL091219 (to BET).

\section{Author details}

'Experimental Oncology/Hematology, Department of Clinical Research, University of Bern, Murtenstrasse 35, CH-3010, Bern, Switzerland.

${ }^{2}$ Department of Molecular and Experimental Medicine, The Scripps Research Institute, La Jolla, CA, USA. 'Department of Medical Oncology, Inselspital, Bern University Hospital, Bern, Switzerland.

Received: 4 August 2012 Accepted: 16 August 2012 Published: 4 September 2012

\section{References}

1. Martin SJ: An Apollon vista of death and destruction. Nature Cell Biology 2004, 6:804-806. 
2. Qiu X-B, Goldberg AL: The membrane-associated inhibitor of apoptosis protein, BRUCE/Apollon, antagonizes both the precursor and mature forms of Smac and caspase-9. J. Biol. Chem. 2005, 280:174-182.

3. Hao Y, Sekine K, Kawabata A, Nakamura H, Ishioka T, Ohata H, Katayama R, Hashimoto C, Zhang X, Noda T, Tsuruo T, Naito M: Apollon ubiquitinates SMAC and caspase-9, and has an essential cytoprotection function. Nat Cell Biol. 2004, 6:849-860.

4. Lopergolo A, Pennati M, Gandellini P, Orlotti NI, Poma P, Daidone MG, Folini $M$, Zaffaroni N: Apollon gene silencing induces apoptosis in breast cancer cells through p53 stabilisation and caspase-3 activation. Br. J. Cancer 2009, 100:739-746.

5. Ren J, Shi M, Liu R, Yang Q-H, Johnson T, Skarnes WC, Du C: The Birc6 (Bruce) gene regulates p53 and the mitochondrial pathway of apoptosis and is essential for mouse embryonic development. Proc. Natl. Acad. Sci. U.S.A. 2005, 102:565-570

6. Ryan BM, O'Donovan N, Duffy MJ: Survivin: A new target for anti-cancer therapy. Cancer Treatment Reviews 2009, 35:553-562.

7. Chen Z, Naito M, Hori S, Mashima T, Yamori T, Tsuruo T: A human IAP-family gene, apollon, expressed in human brain cancer cells. Biochem. Biophys. Res. Commun. 1999, 264:847-854.

8. Van Houdt WJ, Emmink BL, Pham TV, Piersma SR, Verheem A, Vries RG, Fratantoni SA, Pronk A, Clevers H, Borel Rinkes IHM, Jimenez CR, Kranenburg $\mathrm{O}$ : Comparative proteomics of colon cancer stem cells and differentiated tumor cells identifies BIRC6 as a potential therapeutic target. Mol. Cell Proteomics 2011, 10:M111.011353.

9. Chu L, Gu J, Sun L, Qian Q, Qian C, Liu X: Oncolytic adenovirus-mediated shRNA against Apollon inhibits tumor cell growth and enhances antitumor effect of 5-fluorouracil. Gene Therapy 2008, 15:484-494.

10. Carter BZ, Kornblau SM, Tsao T, Wang R-Y, Schober WD, Milella M, Sung $\mathrm{H}-\mathrm{G}$, Reed JC, Andreeff M: Caspase-independent cell death in AML: caspase inhibition in vitro with pan-caspase inhibitors or in vivo by XIAP or Survivin does not affect cell survival or prognosis. Blood 2003, 102:4179-4186.

11. Sung KW, Choi J, Hwang YK, Lee SJ, Kim H-J, Lee SH, Yoo KH, Jung HL, $\mathrm{Koo} \mathrm{HH}$ : Overexpression of Apollon, an Antiapoptotic Protein, Is Associated with Poor Prognosis in Childhood De Novo Acute Myeloid Leukemia. Clin Cancer Res 2007, 13:5109-5114.

12. Ismail EAR, Mahmoud HM, Tawfik LM, Habashy DM, Adly AAM, El-Sherif NH, Abdelwahab MA: BIRC6/Apollon gene expression in childhood acute leukemia: impact on therapeutic response and prognosis. Eur. $J$. Haematol. 2012, 88:118-127.

13. Abe S, Yamamoto K, Hasegawa M, Inoue M, Kurata M, Hirokawa K, Kitagawa $M$, Nakagawa Y, Suzuki K: Bone marrow cells of myelodysplastic syndromes exhibit significant expression of apollon, livin and ILP-2 with reduction after transformation to overt leukemia. Leuk. Res. 2005, 29:1095-1096

14. Ossenkoppele GJ, Graveland WJ, Sonneveld P, Daenen SMGJ, Biesma DH, Verdonck LF, Schaafsma MR, Westveer PHM, Peters GJ, Noordhuis P, Muus P, Selleslag D, van der Holt B, Delforge M, Löwenberg B, Verhoef GEG: The value of fludarabine in addition to ARA-C and G-CSF in the treatment of patients with high-risk myelodysplastic syndromes and AML in elderly patients. Blood 2004, 103:2908-2913.

15. Löwenberg B, Boogaerts MA, Daenen SM, Verhoef GE, Hagenbeek A, Vellenga E, Ossenkoppele GJ, Huijgens PC, Verdonck LF, van der Lelie J, Wielenga JJ, Schouten HC, Gmür J, Gratwohl A, Hess U, Fey MF, van Putten WL: Value of different modalities of granulocyte-macrophage colony-stimulating factor applied during or after induction therapy of acute myeloid leukemia. J. Clin. Oncol. 1997, 15:3496-3506.

16. Löwenberg B, van Putten W, Theobald M, Gmür J, Verdonck L, Sonneveld P, Fey M, Schouten H, de Greef G, Ferrant A, Kovacsovics T, Gratwohl A, Daenen S, Huijgens P, Boogaerts M: Effect of priming with granulocyte colony-stimulating factor on the outcome of chemotherapy for acute myeloid leukemia. N. Engl. J. Med. 2003, 349:743-752.

17. Breems DA, Boogaerts MA, Dekker AW, Van Putten WL, Sonneveld P, Huijgens PC, Van der Lelie J, Vellenga E, Gratwohl A, Verhoef GEG, Verdonck $L F$, Löwenberg B: Autologous bone marrow transplantation as consolidation therapy in the treatment of adult patients under 60 years with acute myeloid leukaemia in first complete remission: a prospective randomized Dutch-Belgian Haemato-Oncology Co-operative Group (HOVON) and Swiss Group for Clinical Cancer Research (SAKK) trial. Br. J. Haematol. 2005, 128:59-65.
18. Federzoni EA, Valk PJM, Torbett BE, Haferlach T, Löwenberg B, Fey MF, Tschan MP: PU.1 is linking the glycolytic enzyme HK3 in neutrophil differentiation and survival of APL cells. Blood 2012, 119:4963-4970.

19. Britschgi C, Jenal M, Rizzi M, Mueller BU, Torbett BE, Andres A-C, Tobler A, Fey MF, Tschan MP: HIC1 tumour suppressor gene is suppressed in acute myeloid leukaemia and induced during granulocytic differentiation. British Journal of Haematology 2008, 141:179-187.

20. Tschan MP, Vonlanthen S, Cajot JF, Peters UR, Oppliger E, Betticher DC, Yarbrough WG, Fey MF, Tobler A: Different p16INK4a and p14ARF expression patterns in acute myeloid leukaemia and normal blood leukocytes. Leuk. Lymphoma 2001, 42:1077-1087.

21. Tschan MP, Shan D, Laedrach J, Eyholzer M, Leibundgut EO, Baerlocher GM, Tobler A, Stroka D, Fey MF: NDRG1/2 expression is inhibited in primary acute myeloid leukemia. Leukemia Research 2010, 34:393-398.

22. Britschgi C, Rizzi M, Grob TJ, Tschan MP, Hügli B, Reddy VA, Andres A-C, Torbett BE, Tobler A, Fey MF: Identification of the $\mathrm{p} 53$ family-responsive element in the promoter region of the tumor suppressor gene hypermethylated in cancer 1. Oncogene 2006, 25:2030-2039.

23. Miranda MB, Dyer KF, Grandis JR, Johnson DE: Differential activation of apoptosis regulatory pathways during monocytic vs granulocytic differentiation: a requirement for $\mathrm{BCl}-\mathrm{X}(\mathrm{L})$ and XIAP in the prolonged survival of monocytic cells. Leukemia 2003, 17:390-400.

24. Tamm I, Richter S, Scholz F, Schmelz K, Oltersdorf D, Karawajew L, Schoch C, Haferlach T, Ludwig W-D, Wuchter C: XIAP expression correlates with monocytic differentiation in adult de novo AML: impact on prognosis. Hematol J 2004, 5:489-495.

doi:10.1186/2162-3619-1-25

Cite this article as: Schläfli et al:: BIRC6 (APOLLON) is down-regulated in acute myeloid leukemia and its knockdown attenuates neutrophil differentiation. Experimental Hematology \& Oncology 2012 1:25.

\section{Submit your next manuscript to BioMed Central and take full advantage of:}

- Convenient online submission

- Thorough peer review

- No space constraints or color figure charges

- Immediate publication on acceptance

- Inclusion in PubMed, CAS, Scopus and Google Scholar

- Research which is freely available for redistribution

Submit your manuscript at www.biomedcentral.com/submit
C Biomed Central 